\title{
Investigar las tradiciones y costumbres de los pueblos es apren- der de la sabiduría originaria
}

\section{To investigate the traditions and customs of the peoples is to learn from the original wisdom}

\author{
Elvira Maritza Andino \\ Directora Departamento de Antropología \\ Facultad de Humanidades y Ciencias Jurídicas \\ UNAN-Managua. Nicaragua. \\ ID Orcid: https://orcid.org/0000-0002-5560-5141 \\ maritzaapicado@hotmail.com
}
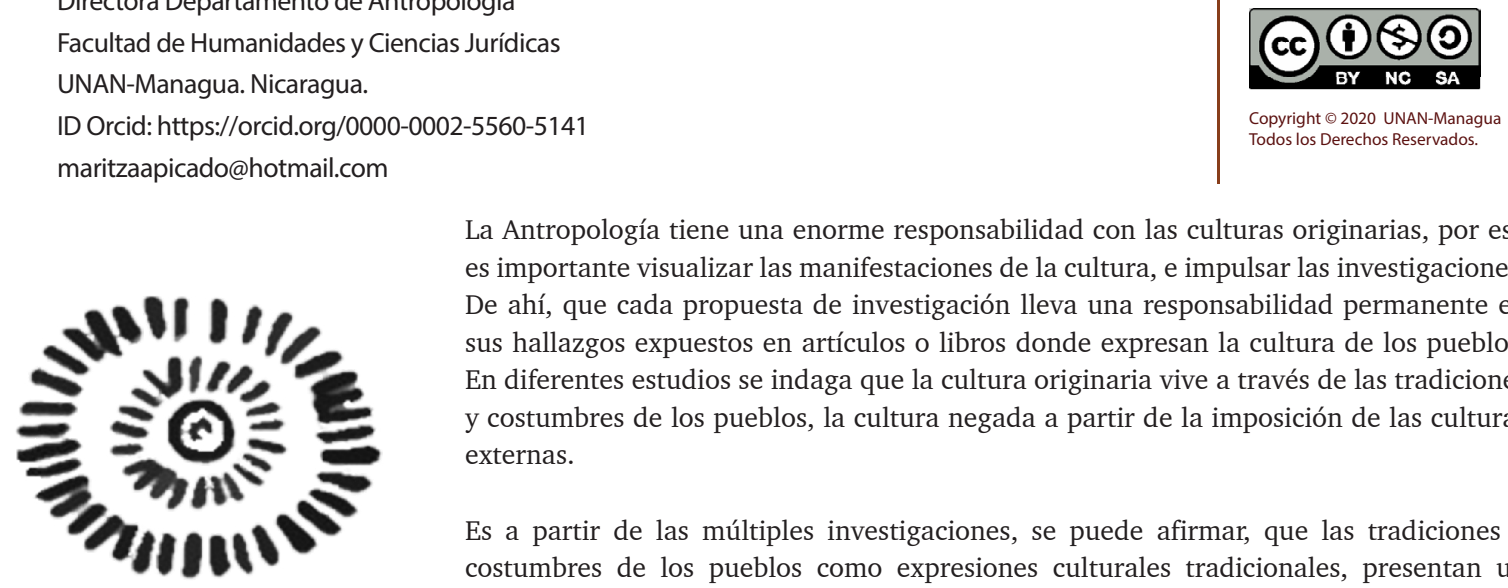

La Antropología tiene una enorme responsabilidad con las culturas originarias, por eso es importante visualizar las manifestaciones de la cultura, e impulsar las investigaciones. De ahí, que cada propuesta de investigación lleva una responsabilidad permanente en sus hallazgos expuestos en artículos o libros donde expresan la cultura de los pueblos. En diferentes estudios se indaga que la cultura originaria vive a través de las tradiciones y costumbres de los pueblos, la cultura negada a partir de la imposición de las culturas externas.

Es a partir de las múltiples investigaciones, se puede afirmar, que las tradiciones y costumbres de los pueblos como expresiones culturales tradicionales, presentan un comportamiento, que se vincula, y se vive por la participación activa en las diferentes prácticas culturales. Los elementos que se confirman en las prácticas culturas, se destacan manifestaciones, por ejemplo el uso del lenguaje, creencias religiosas, expresiones artísticas, conocimiento sobre historia, la forma de vida de las poblaciones entre otras.

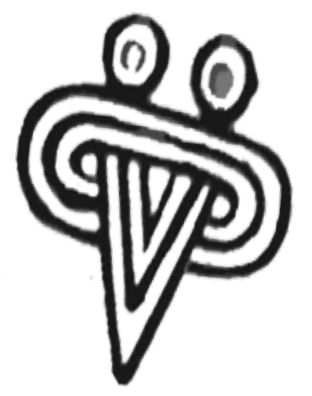

Las poblaciones originarias tienen mucho que decir, por ello el aprendizaje en el El conversatorio con las poblaciones originarios dentro del XII Congreso centroamericano de antropología con sede en Nicaragua, noviembre 2019, se asimiló, que, hay que mantener la mirada hacía los orígenes, seguir aprendiendo de las labores culturales; de la vida artesanal; la economía; la alimentación; la artesanía; la danza, la música; para enamorarnos de su cultura, para retomar los aprendizajes desde las poblaciones.

Debe mantenerse el compromiso en las investigaciones, por eso es importante la decisión de los contextos, de caminar, paso a paso las tierras de las comunidades de los pueblos originarios, con respeto a su sistema de creencias, porque ello, significa la mejor inspiración para desarrollar las investigaciones antropológicas socioculturales, que aporten al desarrollo sostenible de los pueblos y nuestra Nación.

La cultura originaria es sublime, la transmisión de generación en generación reafirma la tradición y de forma implícita sostiene la cultura, de esta manera se presenta la ventana de la cultura originaria. El modo de hacer artesanías, las fiestas patronales, el trabajo,

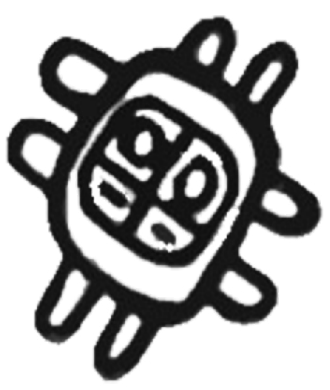
la alimentación, la economía, es una capacidad de mucho valor, que requiere mucho esfuerzo, mucho compromiso con los pueblos originarios. Por ello hay que seguir con el compromiso de preservar las manifestaciones de la cultura originaria.

Las connotaciones valorativas en relación a las manifestaciones de las fiestas patronales, la laboriosidad de hacer cerámica, la atención de los hallazgos de petroglifos en espacios de las familias, los dioses, las huellas artísticas, nos pone en una eminente deuda con los pueblos originarios.

Los antropólogos tienen mucho que hacer e investigar y aportar para que el reconocimiento sea verdaderamente redimible. Seguir investigando para documentar las expresiones culturales que fortalecen el devenir de las poblaciones, es una tarea de alta relevancia y compromiso para los nuevos profesionales de la antropología. 